3. Столярчук О. В. Молодіжний сленг: функційнальний, лексико-семантичний та структурний аспекти : дис. ... канд. філол. наук : 10.02.15. Одеса, 2015. 224 с.

4. Aguilar E. C., Franco E. G. Voces y expresiones del argot juvenil madrileño actual. Círculo de Lingüística Aplicada a la Comunicatión. 2018. № 74. P. 149.

5. Coleman J. The Life of Slang. Oxford: Oxford University Press, 2012. $354 \mathrm{p}$.

6. Harared N. Slang created and used in 1cak.com site: a sociolinguistics study. Humaniora. 2018. Vol. 9, № 2. P. 119-127.

7. Noor R., Laksono A., Kawentar R. Cultural Development through Language Styles and Expression of Teenage Girls Identity in Indonesian Teen lit Novel Me Versus High Heels by Maria Ardelia. ICENIS. 2018. 73. P. 1-2.

8. Wulandari A. Penggunaan jargon oleh komunitas chatting WhatsApp grug. Transformatika. 2016. Vol. 12, № 2. H. 60-72.

DOI https://doi.org/10.30525/978-9934-26-180-0-33

\title{
НАУКОВА КАРТИНА СВІТУ ЯК ОСОБЛИВА ФОРМА СИСТЕМАТИЗАЦІЇ ЗНАНЬ
}

\author{
Товстенко В. P. \\ кандидат філологічних наук, \\ доцент кафедри бізнес-лінгвістики \\ Київський національний економічний університет \\ імені Вадима Гетьмана \\ м. Київ, Украӥна
}

Сукупність наукових знань, релігійних уявлень, естетичних, художніх та моральних цінностей певного соціуму, що проживає на певній території в конкретну історичну епоху - так визначають картину світу сучасні учені $[1$, c.70]. Думка про існування особливого мовного світогляду була сформульована видатним німецьким вченим В.Гумбольдтом ще на початку XIX ст. Він вважав, що людина стає людиною тільки через мову, у якій діють іiі творчі першосили, іiі глибинні можливості, отже, мова - це єдина духовна енергія народу. Мовна картина світу - це знання в мові та знання про мову, тобто мовні знання світу та знання про структуру мови. Мовну картину світу визначають як систему понять, характерну для 
певної мови, за допомогою якої мовці класифікують, інтерпретують навколишній світ; система уявлень певного народу, яка $є$ поняттєво усталеною, закріпленою в системі мови, в їі граматичних та лексичних особливостях, і яка реалізує себе на письмі та в усній мові в кожній мові по-різному [1, с.69]. Наукова картина світу - це цілісний образ реальної дійсності, основою якого є система знань, набутих під час вивчення наук про природу, суспільство, мислення.

Уміння чітко визначати мету наукової комунікації та обирати відповідні мовні засоби для створення текстів необхідного комунікативного спрямування виявляє рівень мовної компетенції учасника комунікації. Наукову мову використовують 3 пізнавально-інформативною метою в галузі науки та освіти. Спільною для суспільної, природничої, технічної та іншої сфер уживання наукової мови є орієнтація на книжну лексику, на логічний виклад інформації, застосування класифікаційного підходу до опису наукових об'єктів, використання абстрактних понять, формулювання дефініцій (визначень). Лексичний та фразеологічний рівні мови наукової літератури характеризує наявність великої кількості термінів відповідних галузей знання, а отже, виразно іменний характер висловлювання ( адже більшість термінологічної лексики - це іменники та інші субстантивовані частини мови). Наука оперує не образами, а поняттями, науковий текст насичений абстрактною лексикою [2, с .403]. Загальновживані слова використовують переважно лише в одному з їхніх значень, тобто наявна функціональна однозначність слова. Характерно, що в суто наукових текстах, призначених для фахівців певної галузі, терміни не пояснюють (напр.: Для гарантованої оплати розрахункових чеків чекодавець бронює кошти на окремому рахунку «Розрахунки чеками» у банку-емітенті. Для иьього разом із заявою на видавання чекової книжки чекодавець подає до банку-емітента платіжне доручення для перерахування коштів на рахунок «Розрахунки чеками»). Для наукового стилю характерні точність, відсутність емоційності та експресивного забарвлення, тому синоніми використовують як засіб контекстуального уточнення (валюта - гроші, грошові знаки, асигнації, банкноти; асигнація - банкнота, кредитка, (кредитний) білет; профіцит - прибуток, зиск, вигода тощо; напр.: Процедура приватизаиії охоплює такі основні елементи: визначення підприємств або їхніх часток (акцій, паӥв), щзо продають громадянам Украӥни за приватизаційні сертифікати, а також часток (акцій, паӥв), щуо продають членам трудових колективів за номінальною вартістю). Своєрідним проявом антонімії $є$ наявність термінів, що позначають протилежні явища, процеси. Наукова мова використовує антоніми як засіб відтворення шляху логічних роздумів, як 
засіб посилення впливу на сприймача інформації (дохід - витрати, попит - пропозиція, актив - пасив, девальвачія - ревальвація, готівковий безготівковий тощо). У науковій мові вживають інтернаціоналізми, власне іншомовні слова, запозичення. Потрібно звернути увагу на те, що слова іншомовного походження більш характерні для власне наукового стилю (напр.: ембарго, емісія, реалізація, конкуренція, конвенція, координація, репарація тощо), а питомі українські - науково-навчального, науково-популярного його різновидів (напр.: заборона, випуск, збут, суперництво, угода, погодження, відикодування тощо). Особливою прикметою мови сучасних науково-технічних термінологічних систем $\epsilon$ активне поповнення новими словами, які виконують у науковій мові номінативну функцію (напр.: іпотека - позика під нерухомість, фритредерство - політика вільної (безмитної) торгівлі, девальвачія зниження курсу тощо). Цікавим аспектом аналізу наукової мови $€$ словотворення. Суфікси та префікси іншомовного походження утворюють загальні й абстрактні назви дії (напр.: делістинг, ревальвація, дисбаланс, депонент, менеджмент, синдикат, картель тощо), надаючи словам відтінку книжності, а осново- та словоскладання є популярним способом творення нових термінів (напр.: платоспроможність, позикоотримувач, лізингодавець, собівартість, иіноутворення, кредитоздатність компанія-донор, компанія-реципієнт, держава-кредитор, держава-рантьє тощо) [3, с. 129]. Свою специфіку наукова мова має на усіх рівнях системи. Наприклад, на морфологічному рівні прагнення до однозначного розуміння викладеного матеріалу спричиняє зменшення ролі дієслів і збільшення кількості іменників (поширені абстрактні та речовинні іменники). Автор наукової праці в основному констатує факти, тому вживані дієслова мають здебільшого форму теперішнього часу. Серед основних характерних ознак наукової мови в синтаксисі переважають складені присудки, означено-особові та безособові односкладні речення тощо. Науковий виклад завжди потребує аргументації авторської думки та виявлення причиново-наслідкових зв'язків, повинен бути логічним і точним, тому для наукових текстів характерні складні й ускладнені речення різних типів. Набір сполучників, особливо підрядних, досить різноманітний; у ролі сполучників часто використовують i прислівникові слова. Перевагу складнопідрядних речень можна пояснити тим, що підрядні конструкції виражають складні причинові, часові, умовні, наслідкові, допустові й інші відношення. Науковий дискурс $\epsilon$ складною єдністю мовної практики та позамовних факторів, необхідних для розуміння тексту наукового характеру. Саме ці фактори дають уявлення про учасників комунікаційної ситуації, їхні цілі, умови 
вироблення і сприйняття повідомлення. У сучасному глобалізованому світі наукова мова є особливим різновидом мови, що функціонує у сфері науки в усній та писемній формах, специфікою якого є формальнологічний спосіб викладення матеріалу, а також вживання спеціальної термінології, використання якої вимагає особливої точності, наявності міркувань, обгрунтування висновків, лаконічності викладу матеріалу, логічної послідовності, смислової завершеності, цілісності. Тісний взаємозв'язок сучасної науки з професійною сферою суспільної діяльності людини зробили популярним поняття фахової мови - форми сучасної української літературної мови, специфіку якої зумовлюють особливості спілкування у виробничо-професійній сфері. Сучасний український соціум в освіті, науці, культурі, діяльності державних інституцій послуговується українською літературною мовою. Українська літературна мова, 3 одного боку, стає мовою сучасного інтелектуального дискурсу в країні, 3 другого - розширення цієї сфери іiі функціонування сприяє інтелектуалізації самої літературної мови, удосконалюючи їі спеціальний різновид мову науки. Термінологія є головним джерелом поповнення лексичного складу високорозвинених сучасних мов. При цьому українська термінологія має низку специфічних проблем, зумовлених історично, а основною потребою сьогодення $є$ створення національних термінологічних стандартів, термінологічних словників тощо. Основною одиницею, якою оперує мова науки, $\epsilon$, безперечно, термін. Існують спільні ознаки, які визначають суть будь-якого терміна як лексичної одиниці спеціального, обмеженого функціонування, а саме: системність (кожен термін входить до певної терміносистеми, в якій має термінологічне значення, за межами своєї терміносистеми термін може мати зовсім інше значення, пор.: ножиці цүін - розбіжність рівнів і динаміка цін у сфері міжнародної торгівлі на окремі групи товарів і значення загальновживаного слова ножиці), наявність визначення ( напр.: дефініцією терміна аудиторський висновок $є$ вислів «документ, що містить результати аудиторської перевірки»), тенденцію до однозначності в межах конкретної системи термінів (наприклад, економічної термінології: ажіо - відхилення курсу цінних паперів від їхньої номінальної вартості в бік перевищення; індосамент - передавальний напис на звороті векселів, чеків та інших цінних паперів; інфляція - надмірне проти потреб товарообігу збільшення кількості паперових грошей i їхнє швидке знецінення тощо), відсутність супровідних експресивних значень, стилістичну нейтральність, точність (термін повинен якнайповніше передавати суть поняття, яке він позначає: короткотерміновий кредит, чекодавець); часте використання багатослівних термінів: міжнародна 
фінансово-господарська операџія, Міжнародне товариство міжбанківських фінансових телекомунікаиій тощо). Термін потрібно вживати лише в одній, зафіксованій у словнику формі, з одним значенням; користуючись терміном, суворо дотримуватись правил утворення від нього похідних форм. Економічні терміни, як і будь-які інші, не однакові за ступенем спеціалізації їхнього значення. Потрібно пам'ятати про поділ терміноодиниць на три основні групи: 1) загальнонаукові терміни, тобто терміни, вживані практично в усіх галузевих термінологіях (напр.: система, тендениія, закон, концепиія, теорія, аналіз, синтез і т. ін.); 2) міжгалузеві терміни, тобто терміни, вживані в кількох споріднених або віддалених галузях (напр.: амортизація, витрати, санація, приватна власність і т. ін.); 3) вузькогалузеві терміни, тобто терміни, характерні лише для певної галузі (напр.: лізинг, банківська гарантія, ажіо, індосант i т. ін.). Важливу роль у мові науки й техніки відіграють міжнародні термінодиниці (макроекономіка, мікроекономіка, індосамент, овердрафт, пан'європейський, дифляиія, іпотека тощо), оскільки полегшують розвиток науково-технічних зв'язків між країнами. За допомогою міжнародних терміноелементів легко побудувати термін у тих випадках, коли з національних терміноелементів створити короткий і точний термін не вдається. Міжнародні терміноелементи легко поєднуються між собою і сприяють подальшому термінотворенню (напр.: аміл-, амфi-, гемi-, гента-, гетер(о)-, гіпер-, гіст(о)-, ди (ді)-, диз-, екс-, контра-, мега-, пан-, полі-, пост-, псевдо-, синхро-, уні-, -тек(а), -фікація, -локаиія тощо). Текст $\epsilon$ продуктом професійного (зокрема, економічного) текстотворення, продуктом конкретної історичної епохи, а як явище мовної та позамовної дійсності - складним феноменом, який бере участь у комунікації, допомагає зберігати й передавати інформацію у просторі й часі. Основні текстові елементи: назва, рубрикація (зміст), перший рядок і останній абзац, які не тільки закладають інтригу творчого пізнання, а й стають концептуальною основою, стрижнем, що підтримує все дослідницьке навантаження [2, с. 679]. Мову і стиль наукового дослідження характеризує чіткість, використання притаманного окремій галузі науки поняттєвого апарату. У науковому тексті лаконічність, зрозумілість, прозорість думки та оригінальність ідеї повинні збігатися з чіткою мовою, короткими фразами, продуманою формою. Одним із сучасних різновидів оформлення тексту є гіпертекст (від грец. «підвищення надмірність» $\mathrm{i}$ «текст») - надтекст, текст вищого рівня, в основі якого лежить принцип нелінійності, вибірковості із системи текстових повідомлень на рівні глобальної мережі інтернет. Часто в науковому тексті мовні засоби виконують роль кліше, якими зручно користуватися, конструюючи ту чи 
іншу думку. Кліше (фран. cliche, від clicher - робити відбиток, стереотипувати) - мовний засіб, стандартний зворот, регулярно повторюваний у певних умовах i контекстах; мовний стереотип 3 позитивною функцією: ринкова економіка, установити контроль, матеріальне благополуччя, ринкові реформи тощо [2, с.255]. Коли кліше бездумно переносяться в усне мовлення, тоді ми маємо справу 3 тим негативним явищем усного мовлення, яке й зветься штампом. Наприклад: На сьогоднішній день питання слабо підняте і висвітлене..,; Заслуговує бути відзначеною така ініціатива...; Подібні факти мають місие на ряді підприємств... та ін. [2, с. 806].

Отже, логіка наукового дослідження тісно пов'язана 3 пошуком найбільш вдалого мовного вираження наукової думки, ідеї. Мовні пошуки вченого «народжують» нове поняття, стають поштовхом до нових наукових ідей. Тому при всій стандартизованості мови сучасних наукових текстів актуальним на сьогодні $є$ розуміння наукового стилю як сукупність індивідуальних мовних стилів дослідників, які постійно творять власні тексти. У мові економічної науки закріплено комплекс наукових знань, тобто вона $є$ складником національної (української) мовної картини світу. Найбільш впливовим фактором іiі становлення $є$ наявність наукової традиції в цій галузі наукових знань про світ, тобто традиції як практичних досліджень частини об'єктивної дійсності, так і теоретичних узагальнень 3 метою отримання нових знань про неї.

\section{Література:}

1. Середницька А.Я. Відмінності між мовною і концептуальною картинами світу 3 погляду сучасного мовознавства. Науковий вісник Міжнародного гуманітарного університету. Сер.: Філологія. № 21. Том 1. 2016. С. 69-71.

2. Українська мова. Енциклопедія / Редкол.: Русанівський В.М. (співголова), Тараненко О.О. (співголова), Заблюк М.П. та ін. 2-ге вид., випр. і доп. Київ: Вид-во «Українська енциклопедія» ім. М. П. Бажана. 2004. $824 \mathrm{c}$.

3. Шарата Н.Г., Кравченко Т.П. Термінологічна номінація понять аграрного сектора економіки. Молодий вчений. № 3(67) березень, 2019. C. $128-132$. 